\title{
Molecular Insights of Some Respiratory Viruses (NDV, IBV, AIV) Affecting Broilers During 2016-2019 In Egypt
}

\section{Marwa Hamed I. Salem ${ }^{1}$, Naglaa M. Hagag², Ahmed A. H. Ali Mohammed Saed M. El-Shahidy ${ }^{4}$}

dr_marwa.vet2011@yahoo.com ${ }^{1}$, naglaahagagahri@gmail.com ${ }^{2}$, ahhmht35@yahoo.com ${ }^{3}$, el_shahidy@yahoo.com ${ }^{4}$

${ }^{I}$ Zagazig branch, Animal Health Research Institute, Dokki, Giza, Egypt.

${ }^{2}$ RLQP., Animal Health Research Institute, Dokki, 12618Giza.P.O. Box 246

Egypt. ${ }^{3}$ Department of Virology, Faculty of Veterinary Medicine, Zagazig

University, Zagazig, Egypt. ${ }^{4}$ Department of Virology, Faculty of Veterinary

Medicine, Suez Canal University, Ismailia, Egypt.

${ }^{1}$ Corresponding author: Marwa Hamed Ibraheem Salem.

Address: Department of virology, Animal Health Research Institute, Zagazig, 44516, Egypt. Phone : 01225071100

\begin{abstract}
Newcastle disease virus (NDV), Infectious bronchitis virus (IBV) and avian influenza virus (AIV) are the most important respiratory viruses. Many outbreaks have been reported in Egypt in spite of the intensive use of vaccination due to the wide variations in the serotypes, the highly contagious nature, the evolution of specific tissue tropism and the mutations due to simultaneous infection of multiple virus types and use of live vaccines. In this study, 10 broiler flocks in Ismailia, Sharkeia, Gharbia, Dakahleia and Matrooh suffered of severe respiratory illness with high mortalities were examined. A total of 138 nasal swabs and 144 tissue pools (brain, trachea, lung, liver, proventriculus, spleen, kidney, intestine and cecal tonsils) were collected from affected chickens and tested with Real Time RT-PCR (qRT-PCR) assay. Total positivity percentages of each virus in chickens were $23.46 \%$ for NDV, $18.08 \%$ for IBV and $31.20 \%$ for AIV. Three NDV, three IBV and four AIV sequences out of 208 positive samples were selected for sequence analysis of F, S1 and M gene respectively. The sequence analysis of F gene of NDV revealed that all isolates were clustered in genotype VII and exhibited the cleavage site $\left({ }^{112} \mathrm{RRQKRF}^{117}\right)$ of virulent velogenic NDVs. The S1 gene of IBV showed that the three isolates were closely related to variant II IBV strains. The $\mathrm{M}$ gene sequence analysis revealed that two AI isolates belonged to $\mathrm{H} 9 \mathrm{~N} 2$ and two AI isolates belonged to $\mathrm{H} 5 \mathrm{~N} 8$ subtypes.
\end{abstract}


Keywords: Respiratory viruses, Newcastle Disease virus (NDV), Avian influenza virus (AIV), Infectious Bronchitis virus (IBV), genetic diversity.

\section{Introduction}

Respiratory tract infections are of the greatest importance in poultry industry worldwide, causing high economic losses. The major economic losses are due to high morbidities and mortalities (1). A wide variety of bacterial and viral pathogens responsible for respiratory infections in poultry, particularly NDV, IBV and AIV, which can cause disease alone or in mixed infections (2).

NDV is a negative sense, singlestranded RNA virus and has only one serotype belonging to the family Paramyxoviridae (3). According to virulence of strains, NDV is classified into three pathotypes: velogenic strains (highly virulent), mesogenic strains (intermediate virulence) and lentogenic strains (low virulent) (4, 5). NDVs are classified according to the partial sequence of $\mathrm{F}$ protein cleavage site into two classes, Class I is generally of low virulence while Class II exhibits the majority of velogenic virulent strains and contains eighteen genotypes and subgenotypes $(6,7)$.

IBV is an enveloped, positivesense, with ssRNA genome which belongs to the family Coronaviridae. More than 50 serotypes have been reported since the first IBV identification in 1936 (A). IBV genome have 4 structural
(Spike, envelope, matrix and nucleoprotein) and 2 nonstructural genes. Spike protein 1 gene (S1) is the major antigenic determinants and serotype specific protein (9). IBV readily undergoes mutation in $\mathrm{S} 1$ gene resulting in the emergence of new variant serotypes and genotypes that escape vaccination causing major respiratory problems in the farm (8).

AIV is a negative sense, segmented (8 segments), with ssRNA, AI virus belonging to influenza $A$ virus of the family Orthomyxoviridae (10). Genetic shift and drift occur frequently during influenza viral replication, due to lacking of the proof reading and the genome segmentation generating replication errors (11), the resultant changes allow the virus to evade neutralizing antibody; such changes may lead to the creation of a new virus strain differ from those previously circulating viruses (12). Matrix protein is an important integral genus specific protein that determine the virus morphology (13). Based on the antigenicity of the two surface proteins (HA\& NA), Influenza A viruses have at least 18 subtypes of hemagglutinin (HA) and 11 subtypes of neuraminidase (NA) (14). AIV can be divided into two groups depending on the severity of infections in poultry: highly 
pathogenic avian influenza virus (HPAIV) and low pathogenic avian influenza virus (LPAIV) (12).

In spite of using intensive vaccination of chickens against NDV, IBV and AIV in poultry farms in Egypt, new variants of the three viruses can emerge evading chickens, vaccination causing major respiratory problems. These genetic variations in the genome of the three viruses needs periodical analysis and characterization, therefore, the present study aimed to identify and analyze the evolutionary changes of NDV, IBV and AIV subtypes circulated in 5 provinces in Egypt and involved in the respiratory manifestation of broiler chickens during 2016-2019.

\section{Materials and Methods \\ Reference viruses}

NDV (accession no. KU365663), AIV H5N8\& H5N1\& H9N2 (accession no. MH893738 \& KP209303 \& MH762070) and IBV (accession no. KT832809) were isolated from Egyptian poultry farms, characterized and fully identified in RLQP -animal health research institute, Dokki, Egypt and used as positive controls. Virus strains were propagated in 9-d-old embryonated chicken eggs up to 3 passages and tested according to method described by (15).

\section{Clinical Samples}

A total number of 138 nasal swabs and 144 tissue samples (brain, trachea, lung, liver, proventriculus, spleen, kidney, intestine and cecal tonsils) were collected from broiler farms in five Egyptian governorates (El Sharkeia, El Dakhleia, El Gharbeia, Matrooh and Ismailia). Individual tissue samples from each bird were pooled in one tube. All chicken samples suffered from severe respiratory illness with mortalities ranged between 5 and $20 \%$. Nasal swabs and tissue pools were prepared and processed according to the methods described by $(16,17)$.

\section{RNA extraction}

Total RNA was extracted from swabs, tissue pools and all reference virus isolates using Dynabeads $®$ SILANE viral NA Kit (Invitrogen) Catalog no. 37011D. Extraction of total RNA were carried out using spin column according to the manufacturer's instructions.

\section{Primer and Probe design}

Three sets of primers and probes were used for detection of NDV, AIV and IBV in qRT-PCR. Primers and Probes were specifically amplifying $\mathrm{F}$ gene of NDV, NP gene of IBV and $\mathrm{M}$ gene of AIV in the qRT-PCR (Table 1), and to amplify F gene of NDV, S1 gene of IBV and $M$ gene of AIV in the conventional RT-PCR (Table 2). The sequence of the primers and probes were obtained from published data in literature and synthesized by Operon Biotechnologies (Huntsville, AL).

\section{qRT-PCR}

qRT-PCR employed in the present work consisted of a reverse transcription kits with master mix 
PCR amplification kits, enzymes and buffers in a single step. For this purpose, reverse transcription kits (Invitrogen), PCR master mix (Invitrogen) and qRT-PCR apparatus (Applied Biosystem) were used. following the protocol of the manufacturers. The cycling temperature conditions as follows $30 \mathrm{~min}$ at $48^{\circ} \mathrm{C}$, followed by $10 \mathrm{~min}$ at $95^{\circ} \mathrm{C}$, with a subsequent 40 cycles of amplification $\left(95^{\circ} \mathrm{C}\right.$ for 15 $\mathrm{s} ; 60^{\circ} \mathrm{C}$ for $1 \mathrm{~min}$; fluorescence was recorded at $\left.60^{\circ} \mathrm{C}\right)(18)$.

\section{conventional RT-PCR}

For RT-PCR, the target sequences were fusion protein gene of NDV, spike protein gene of IB and matrix gene of AI. Amplification of each one of the 3 RNA viruses (NDV, IBV and AIV) were done in uniplex RT-PCR using SuperScriptTM III One-Step RT-PCR kit with Platinum ${ }^{\circledR T a g}$ (INVITROGEN). Reverse transcription was carried out at $50^{\circ} \mathrm{C}$ for 30 minutes followed by $95^{\circ} \mathrm{C}$ for 15 minutes to inactivate RT enzyme. The PCR conditions used were 35 cycles of $94^{\circ} \mathrm{C}$ for 15 seconds (denaturation), $52^{0} \mathrm{C}$ for 30 seconds (annealing), and $72^{\circ} \mathrm{C}$ for 90 seconds (extension). After 35 cycles of PCR, final extension was carried out at $72^{0} \mathrm{C}$ for 5 minutes.

\section{Sequencing analysis}

Three PCR products of each NDV, IBV and four of AIV of the were purified and used for sequencing and sequence analysis. The PCR products were purified using QIAquick PCR Purification Kits,
QIAGEN, Germany, as described in the manufacture's protocol. The purified PCR products then have been amplified using fluorescent dye-labeled-dideoxinucleotides as chain terminator (BigDye ${ }^{\circledR}$ Terminator Cycle Sequencing Kit, Applied Biosystems, USA) in a single sequencing reaction tube on Thermocycler (Biometra, Germany). The sequencing results were analyzed in an automated DNA sequencer $(3500$ Genetic Analyzers, Applied Biosystems, USA). Sequencing reaction purification has been carried out using Centri-SepTM Columns, Applied Biosystems, and USA.

\section{Phylogenetic analysis}

BLAST search of AIV $M$ gene, NDV $F$ gene and IBV S1 gene against data base in gene bank were carried out and the BLAST results were analyzed. Sequence identity, divergence and phylogenic relationships were performed using (clustal W) method with weighted residue and the Mega 5 and Bioedit program (DNASTAR, Inc. Madison, WI, USA) as described by (19). phylogenetic trees based on the partial sequences of the three genes mentioned above were constructed and analyzed.

\section{Results}

\section{1. $q R T$-PCR}

Nasal swabs and tissue pools of chickens suspected to be infected with NDV, AIV and IBV were examined by qRT-PCR using specific primers and probes for 
NDV, AIV and IB. All primer-probe pairs reacted only with their corresponding with mean $\mathrm{Ct}$ values ranged from 24.5-32.1 for AIV, 23.827 for NDV and 26.3-31.2 for IBV. Incidence of each virus in each province with the positivity percentages were recorded in (table 3).

\section{2. conventional $R T$-PCR}

The assay produced amplicons of expected sizes that were distinguishable in the agarose gel; 400bp, $700 \mathrm{bp}$ and 124bp PCR products from cDNA of known NDV, IBV and AIV respectively.

\section{Sequencing and Phylogenetic analysis}

\subsection{NDV F gene}

Three NDV positive samples were selected from different governorates (Ismailia, Sharkia and Gharbia province) to be sequenced and compared with the known genotypes of APMV-1 circulating worldwide. Phylogenetic analysis was based on partial $F$ gene sequence for reference viruses and Egyptian strains from gene bank (table 4). The three Egyptian NDV strains were closely related to each other and to NDV strains circulated recently in Egypt. In the phylogenetic tree of NDV Egypt strains based on nucleotide sequences revealed that the three strains, clearly clustered with sequences of virulent genotype VII viruses of Egypt and other worldwide virulent NDV strains (Fig. 1).

Deduced amino acid sequences of the $\mathrm{F}$ protein cleavage site of Egypt NDV strains, GRRQKR*F (aa 111-
117), was indicative of high virulent NDV strains. Deduced amino acid alignment of $\mathrm{F}$ gene of three recent Egyptian NDV strains 2019 with other reference vaccinal lentogenic and mesogenic strains revealed three or more specific amino acid arginine $(\mathrm{R})$ or lysine $(\mathrm{K})$ starting at position 113 and a phenylalanine (F) at position 117 specific for virulent NDV strains and not found in mesogenic or lentogenic strains.

\subsection{IB V S1 gene}

Three recent Egyptian IBV strains out of the IBV positive samples were selected from Ismailia, Sharkia and Gharbia province for sequencing and phylogenetic analysis. Three partial S1 gene sequences of IBV were phylogenetically compared with each other and with representatives of 17 distinct known IBV circulating worldwide. Phylogenetic analysis was based on the full S1 gene sequence for reference vaccinal virus strains and a partial nucleotide sequence. The three Egyptian sequences were identical to each other with identity percentages ranged between 91.3 to $98.1 \%$ (table 5). The three strains were identical to other IBV strains circulating in Egypt 2016 and other distributed worldwide with identity percentage ranged between 70.5 and 91.4\%. The three IBV Egyptian strains were clustered with variant II IBV strains (Fig. 2). Mutations in amino acids of HVR of Egyptian IBV strains, the number of mutations were very high in 
comparison to IBV-IB-VAR206spike-glycoprotein as reference strain; Classic IBV strains had 22 mutations, Variant I had 28 mutations, Variant II had 14 mutations, IBVCH-EGYPT-M12019-SP1 had 16 mutation, IBVCH-EGYPT-M2-2019-SP1 had 18 mutations and IBV-CH-EGYPTM3-2019-SP1 had 17 mutations, all at different positions.

\subsection{AIV M gene}

Four samples out of the AIV positive samples by qRT-PCR from Ismailia, Sharkia, Dakhlia and Gharbia province were selected for sequencing of $\mathrm{M}$ gene. Partial $\mathrm{M}$ gene sequences of the two strains (Ismalia and Gharbia) strains were identical and clustered with $\mathrm{H} 9$ influenza $\mathrm{A} /$ chicken/Egypt viruses circulating in 2017, while the other two AIV isolates of (Sharkia and Dakhlia) were clustered with H5 AIV circulating in Egypt 2018 (M12018-H5N8 and M2-2018-H5N8). They clustered with G1- like viruses and were closely related to strains from Libya, Tunisia, Saudi Arabia, and Pakistan collected from 2005 through 2015 (fig. 3).

At the amino acid and nucleotide level the two H5 strains showed $97.8 \% \& 97.8$ and $98.5 \& 98.1 \%$ identity with A/littlegrebe/Egy/ 1056OP/2016, respectively, meanwhile H9 AIV isolates (M32018-H9N2 and M4-2018-H9N2) showed 97.1 and $99.3 \%$ homology to $\mathrm{A} / \mathrm{qu} / \mathrm{Egy} / 113413 \mathrm{v} / 2011(\mathrm{H} 9 \mathrm{~N} 2)$ (table 6)

Table (1): Primer and Probe sequences used for $q R T-P C R$.

\begin{tabular}{|c|c|}
\hline IBV-F & 5-GCTTTTGAGCCTAGCGTT-3 \\
\hline IBV-R & 5-GCCATGTTGTCACTGTCTATTG-3 \\
\hline IBV-PROBE & 5-FAM-CACCACCAGAACCTGTCACCTC-BHQ1-3 \\
\hline NDV-F & 5-TCCGGAGGATACAAGGGTCT-3 \\
\hline NDV-R & 5-AGCTGTTGCAACCCCAAG-3 \\
\hline NDV-PROBE $(\mathbf{V F P - 1 )}$ & 5-FAM-AGCGTTTCTGTCTCCTTCCTCCA-TAMRA-3 \\
\hline sepro-01 & 5-AGA TGA GTC TTC TAA CCG AGG TCG-3 \\
\hline Sepro-02 & 5-TGC AAA AACATC TTC AAG TCT CTG-3 \\
\hline Sepro-probe & 5-FAM-TCAGGCCCCCTCAAAGCCGA-BHQ1-3 \\
\hline
\end{tabular}


Table (2): Oligonucleotide primers used in RT-PCR and length of the amplified products.

\begin{tabular}{|c|c|c|c|c|}
\hline Virus & $\begin{array}{c}\text { Primer } \\
\text { name }\end{array}$ & Primer Sequence & $\begin{array}{c}\text { Product } \\
\text { size }\end{array}$ & Reference \\
\hline NDV & $\begin{array}{c}\text { F330 } \\
\text { R700 }\end{array}$ & $\begin{array}{c}\text { 5-AGG AAG GAG ACA AAA ACG TTT TAT AGG-3 } \\
\text { 5-TCA GCT GAG TTA ATG CAG GGG AGG-3 }\end{array}$ & 400bp & $\begin{array}{c}\text { (Naglaa } \text { et } \\
\text { al.,2014) }\end{array}$ \\
\hline IBV & HVR1-2-F & 5- GTKTACTACTACCARAGTGC -3 & 700bp & $\begin{array}{c}\text { (Gelb } \text { et } \\
\text { al., 2005), } \\
\text { (Adzhar } \text { et } \\
\text { al.,1997) }\end{array}$ \\
\hline AVR1-2R & 5- GAAGTGRAAACRAGATCACCATTTA -3 & 5-AAAGCAGGAAGATGTTGAAAGA-3 & 124bp & $\begin{array}{c}\text { (Friedrich- } \\
\text { Loeffler- } \\
\text { Institute) }\end{array}$ \\
\hline
\end{tabular}

Codes for mixed bases positions: $R, A / G ; K, G / T$.

Table (3): Positivity percentages and Ct value of qRT-PCR for NDV, AIV and IBV in Egyptian provinces

\begin{tabular}{|c|c|c|c|c|c|c|c|c|c|}
\hline \multirow{2}{*}{ Govern/total } & \multicolumn{3}{|c|}{ NDV positive } & \multicolumn{3}{c|}{ AIV positive } & \multicolumn{3}{c|}{ IBVositive } \\
\cline { 2 - 10 } & Ct & No. & \% & Ct & No. & \% & Ct & No. & \% \\
\hline Sharkia-Swabs (40) & 24.6 & 10 & 25 & 24.5 & 12 & 30 & 28.1 & 8 & 20 \\
Tissue pools (22) & 23.5 & 8 & 36.4 & 28.2 & 10 & 45.5 & 27.4 & 4 & 18.2 \\
Dakahlia- swabs (8) & 26.1 & 1 & 12.5 & 29.4 & 2 & 25 & 26.3 & 2 & 25 \\
Tissue pools (5) & 27.0 & 1 & 20 & 28.0 & 2 & 40 & 31.2 & 1 & 20 \\
Gharbia-Swab (50) & 25.5 & 10 & 20 & 32.1 & 13 & 26 & 30.4 & 10 & 20 \\
Tissue pool (60) & 26.3 & 13 & 21.7 & 29.0 & 15 & 25 & 28.4 & 8 & 13.3 \\
Matrouh-Swab (10) & 24.8 & 3 & 30 & 24.6 & 5 & 30 & 27.8 & 3 & 30 \\
Tissue pool (17) & 25.4 & 7 & 41.2 & 27.2 & 8 & 47.1 & 28.4 & 5 & 29.4 \\
Ismailia-Swab (30) & 25.3 & 10 & 33.3 & 28.4 & 10 & 33.3 & 26.8 & 3 & 10 \\
Tissue pool_(40) & 23.8 & 6 & 15 & 26.6 & 11 & 27.5 & 27.7 & 7 & 17.5 \\
\hline Total (282) & & 69 & 23.46 & & 88 & 31.20 & & 51 & 18.08 \\
\hline
\end{tabular}

Table (4): Amino acid identity and divergence of 3 Egyptian NDV strains 2019 with reference vaccinal NDV strains. 
Percentidentity

\begin{tabular}{|c|c|c|c|c|c|c|c|c|c|c|c|}
\hline & 1 & 2 & 3 & 4 & 5 & 6 & 7 & 8 & 9 & 10 & \\
\hline 1 & & 80.4 & 80.4 & 78.3 & 84.1 & 93.5 & 78.3 & 99.3 & 99.3 & 99.3 & 1 \\
\hline 2 & 22.7 & & 100.0 & 97.8 & 87.7 & 83.3 & 86.2 & 81.2 & 81.2 & 81.2 & 2 \\
\hline 3 & 22.7 & 0.0 & & 97.8 & 87.7 & 83.3 & 86.2 & 81.2 & 81.2 & 81.2 & 3 \\
\hline 4 & 25.7 & 2.2 & 2.2 & & 85.5 & 81.2 & 84.1 & 79.0 & 79.0 & 79.0 & 4 \\
\hline 5 & 18.0 & 13.5 & 13.5 & 16.1 & & 87.0 & 92.0 & 83.3 & 83.3 & 83.3 & 5 \\
\hline 6 & 6.8 & 18.9 & 18.9 & 21.8 & 14.4 & & 81.9 & 92.8 & 92.8 & 92.8 & 6 \\
\hline 7 & 25.7 & 15.3 & 15.3 & 18.0 & 8.4 & 20.8 & & 77.5 & 77.5 & 77.5 & 7 \\
\hline 8 & 0.7 & 21.8 & 21.8 & 24.7 & 18.9 & 7.6 & 26.8 & & 100.0100 .0 & 8 \\
\hline 9 & 0.7 & 21.8 & 21.8 & 24.7 & 18.9 & 7.6 & 26.8 & 0.0 & & 100.0 & 9 \\
\hline 10 & 0.7 & 21.8 & 21.8 & 24.7 & 18.9 & 7.6 & 26.8 & 0.0 & 0.0 & & 10 \\
\hline & 1 & 2 & 3 & 4 & 5 & 6 & 7 & 8 & 9 & 10 & \\
\hline
\end{tabular}

APINV-CH-China-SDWF07-011-V-VII

NDV-isolate-Hitchner-fusion-genes

NDV-done-30

NDV-VG-GA-(avinew)

vectormune-ND-strain

NDV-KBNP.C4152R2L(DALGUBAL-N*)

NDV-chicken-N-Ireland-Ulster-67

NDV-EGY-N1-F-2019

NDV-EGY-HI2-F-2019

NDV-EGY-H3-F-2019

Table (5): Identity and divergence percentages of recent Egyptian IBV sequence with other strains circulating in Egypt and worldwide.

\begin{tabular}{|c|c|c|c|c|c|c|c|c|c|c|c|c|c|c|c|c|c|c|c|c|c|}
\hline & \multicolumn{21}{|c|}{ Percentidertity } \\
\hline & 1 & 2 & 3 & 4 & 5 & 6 & 7 & 8 & 9 & 10 & 11 & 12 & 13 & 14 & 15 & 16 & 17 & 18 & 19 & 20 & \\
\hline 1 & & 100.0 & 89.5 & 89.5 & 77.1 & 790 & 78.1 & 7908 & 829 & 85.7 & 829 & 81.9 & 79.08 & 80.0 & 100.0 & 924 & 89.5 & 83.8 & 81.9 & 829 & 1 \\
\hline 2 & 0.0 & & 89.5 & 89.5 & 77.1 & 790 & 78.1 & 7908 & 829 & 85.78 & 82.9 & 81.9 & 79.08 & 80.0 & 100.0 & 924 & 89.5 & 838 & 81.9 & 829 & 2 \\
\hline 3 & 11.3 & 113 & & 100.0 & 790 & 81.0 & 890 & 81.0 & 81.9 & 8298 & 829 & 81.0 & 81.08 & 81.0 & 89.5 & 819 & 89.5 & 924 & 924 & 924 & 3 \\
\hline 4 & 113 & 113 & 0.0 & & 790 & 81.0 & 80.0 & 81.0 & 81.9 & 8298 & 82.9 & 81.0 & 81.0 & 810 & 89.5 & 81.9 & 89.5 & 924 & 924 & 924 & 4 \\
\hline 5 & 273 & 27.3 & 246 & 246 & & 98.1 & 91.4 & 98.17 & 7627 & 7437 & 724 & 724 & 88.17 & 724 & 77.1 & 70.5 & 743 & 73.3 & 743 & 743 & 5 \\
\hline 6 & 24.6 & 246 & 220 & 220 & 19 & & 93.3 & 10007 & 78.17 & 7627 & 74.3 & 72.4 & 1000.07 & 724 & 79.0 & 724 & 762 & 752 & 762 & 762 & 6 \\
\hline 7 & 26.0 & 260 & 23.3 & 233 & 9.1 & 70 & & 93.37 & 762 & 76.27 & 74.3 & 73.3 & 93.37 & 73.3 & 78.1 & 70.5 & 78.1 & 743 & 752 & 752 & 7 \\
\hline 8 & 24.6 & 246 & 220 & 220 & 19 & 0.0 & 70 & & 78.1 & 7627 & 743 & 724 & 100.07 & 724 & 790 & 724 & 762 & 752 & 762 & 762 & 8 \\
\hline 9 & 19.5 & 19.5 & 20.8 & 208 & 287 & 260 & 28.7 & 250 & & 829 & 829 & 829 & 78.18 & 80.0 & 829 & 752 & 80.0 & 79.0 & 77.1 & 78.1 & 9 \\
\hline 10 & 15.9 & 159 & 19.5 & 19.5 & 315 & 287 & 28.7 & 28.71 & 19.5 & & 85.7 & 85.7 & 7628 & 848 & 85.7 & 78.18 & 83.8 & 78.1 & 77.1 & 781 & 10 \\
\hline 11 & 19.5 & 19.5 & 19.5 & 19.5 & 345 & 31.5 & 31.5 & 31.51 & 19.5 & 14.7 & & 952 & 74.39 & 952 & 829 & 752 & 81.9 & 78.1 & 78.1 & 0 & 11 \\
\hline 12 & 20.8 & 20.8 & 220 & 220 & 345 & 345 & 33.0 & 3451 & 19.5 & 15.9 & 49 & & 724 & 962 & 81.9 & 743 & 800 & 762 & 752 & 762 & 12 \\
\hline 13 & 24.6 & 246 & 220 & 220 & 19 & 0.0 & 70 & 0.02 & 2500 & 28.73 & 31.5 & 34.5 & & 724 & 790 & 724 & 762 & 752 & 762 & 762 & 13 \\
\hline 14 & 233 & 23.3 & 220 & 220 & 345 & 345 & 330 & 3452 & 23.3 & 17.1 & 49 & 39 & 345 & & 80.0 & 73.3 & 790 & 762 & 762 & 77.1 & 14 \\
\hline 15 & 0.0 & 0.0 & 11.3 & 113 & 27.3 & 246 & 25.0 & 2461 & 19.5 & 159 & 19.5 & 20.8 & 24.62 & 23.3 & & 924 & 89.5 & 838 & 81.9 & 829 & 15 \\
\hline 16 & 8.1 & 8.1 & 208 & 208 & 37.5 & 345 & 37.5 & 3453 & 30.12 & 25.03 & 30.1 & 31.5 & 345 & 33.0 & 8.1 & & 81.9 & 762 & 752 & 762 & 16 \\
\hline 17 & 11.3 & 11.3 & 11.3 & 113 & 31.5 & 287 & 260 & 28.72 & 23.3 & 1832 & 20.8 & 23.3 & 28.72 & 24.6 & 1132 & 20.8 & & 848 & 81.9 & 83.8 & 17 \\
\hline 18 & 18.3 & 18.3 & 8.1 & 8.1 & 330 & 30.1 & 31.5 & 30.12 & 24.6 & 2802 & 26.0 & 28.7 & 30.12 & 28.7 & 18.32 & 28.7 & 17.1 & & 91.4 & 933 & 18 \\
\hline 19 & 20.8 & 20.8 & 8.1 & 8.1 & 31.52 & 287 & 30.1 & 23.72 & 27.3 & 27.32 & 26.0 & 30.1 & 28.72 & 28.7 & 2083 & 30.1 & 20.8 & 9.1 & & 98.1 & 19 \\
\hline 20 & 19.5 & 19.5 & 8.1 & 8.1 & 31.52 & 287 & 30.1 & 28.72 & 2500 & 28.02 & 24.6 & 28.7 & 28.72 & 27.3 & 1952 & 28.7 & 183 & 70 & 1.9 & & \\
\hline & 1 & 2 & 3 & 4 & 5 & 6 & 7 & 8 & 9 & 10 & 11 & 12 & 13 & 14 & 15 & 16 & 17 & 18 & 19 & 20 & \\
\hline
\end{tabular}

IBV-ABVIR2-05-spike-gljcoprotain IBV-attenualed-14-1434-06-spite IBV-Eg-12120s-2012-spine |B|-Eg-121978-2012-spice IBVIEGTF-013 IB|-Ha5-SP1 IBV-Connedicut |BV-||41 IBV.0274 IBV-OVOK-SP1 IBV-UK-491 IBICRB8121 |B|-H120-spike-proteinAian-1BV-variant-1.S1 IBV-Eg-CLEIB-2-8V-012-spice IBV-Eg-CLEIB-1-BVV12-spice Aian-1BV-IS-885-S1-5pive IBV-CH-EGIPT-II1-2019-SP1 IBV-CH-EGIPTHL-2019-SP1 |BV-CH-EGIPTII3-2019-SP1 
Table (6): Amino acid sequence identities and divergences between the Egyptian AIV isolates.

Percentidentity

\begin{tabular}{|c|c|c|c|c|c|c|c|c|c|c|c|}
\hline & 1 & 2 & 3 & 4 & 5 & 6 & 7 & 8 & 9 & 10 & \\
\hline 1 & & 100.0 & 100.0 & 97.8 & 98.5 & 92.7 & 92.7 & 92.7 & 94.2 & 93.4 & 1 \\
\hline 2 & 0.0 & & 1000.0 & 97.8 & 98.5 & 92.7 & 92.7 & 92.7 & 94.2 & 93.4 & 2 \\
\hline 3 & 0.0 & 0.0 & & 97.8 & 98.5 & 92.7 & 92.7 & 92.7 & 94.2 & 93.4 & 3 \\
\hline 4 & 2.2 & 2.2 & 2.2 & & 99.3 & 90.5 & 90.5 & 90.5 & 92.0 & 91.2 & 4 \\
\hline 5 & 1.5 & 1.5 & 1.5 & 0.7 & & 91.2 & 91.2 & 91.2 & 92.7 & 92.0 & 5 \\
\hline 6 & 7.8 & 7.8 & 7.8 & 10.3 & 9.4 & & 1000.0 & 100.0 & 97.1 & 99.3 & 6 \\
\hline 7 & 7.8 & 7.8 & 7.8 & 10.3 & 9.4 & 0.0 & & 100.0 & 97.1 & 99.3 & 7 \\
\hline 8 & 7.8 & 7.8 & 7.8 & 10.3 & 9.4 & 0.0 & 0.0 & & 97.1 & 99.3 & 8 \\
\hline 9 & 6.1 & 6.1 & 6.1 & 8.6 & 7.7 & 3.0 & 3.0 & 3.0 & & 97.8 & 9 \\
\hline 10 & 7.0 & 7.0 & 7.0 & 9.5 & 8.6 & 0.7 & 0.7 & 0.7 & 22 & & 10 \\
\hline & 1 & 2 & 3 & 4 & 5 & 6 & 7 & 8 & 9 & 10 & \\
\hline
\end{tabular}

A-littegrebe-Egy-10560P-2016(H5N8)

A-ouck-Eg)-F13666A-2017(H5N8)

A-ch-Egy-0138044-2017(HFNB)

M1-2018-H5N8

M2-2018-H5N8

A-qu-Eg/:113413v-2011(H9N2)

A-ch-Egj-S7404-2013/H9N2)

A-ch-Egy)-F109938-2015(H9N2)

M3-2018-H9N2

IM4-2018-H9N2 


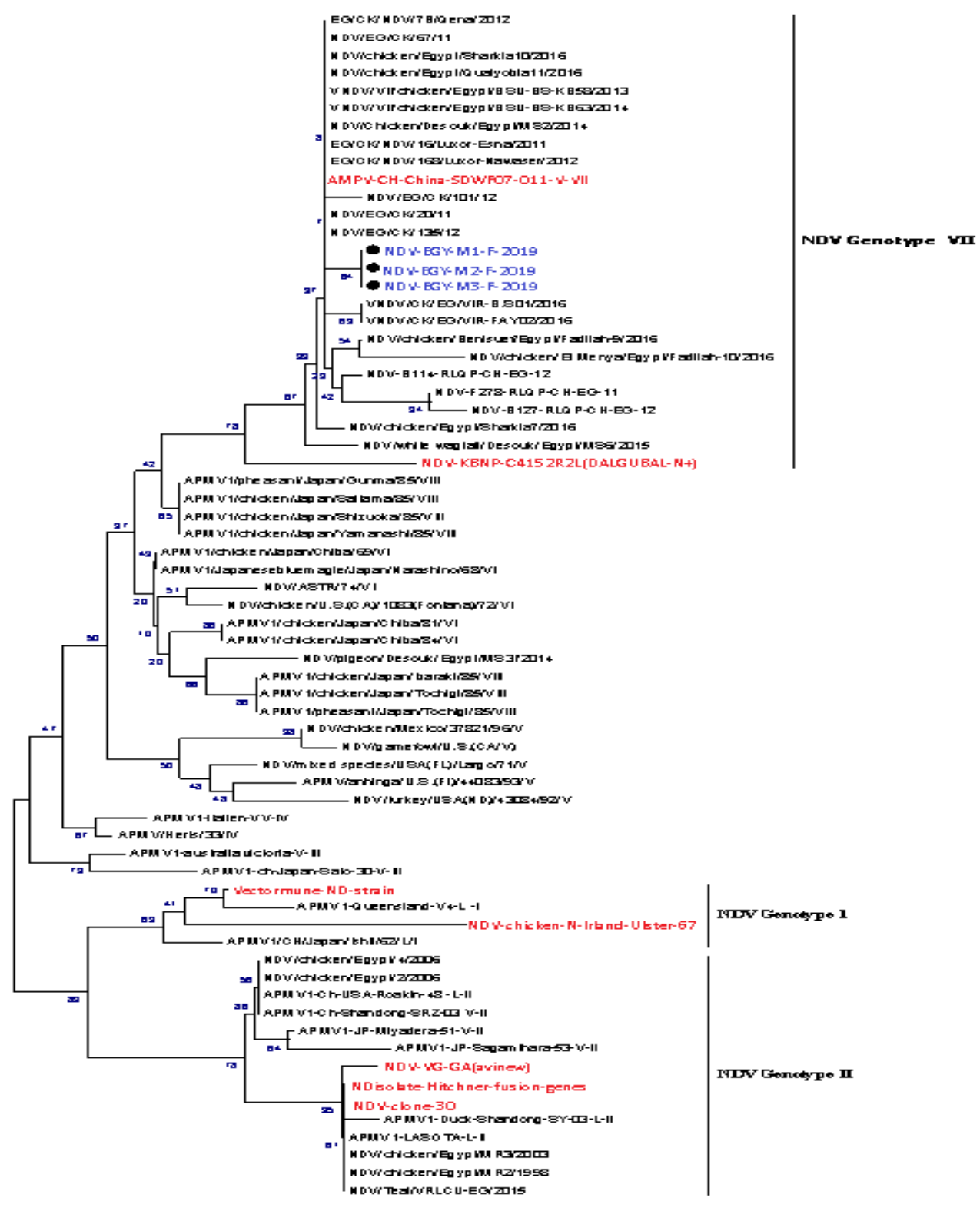

Fig. (1): A Phylogenetic tree of $F$ gene sequence of recent three Egyptian NDV isolates 2019 (with black solid circle and written in blue), clustered within genotype VII Egypt strains circulating between 2011 - 2017. 


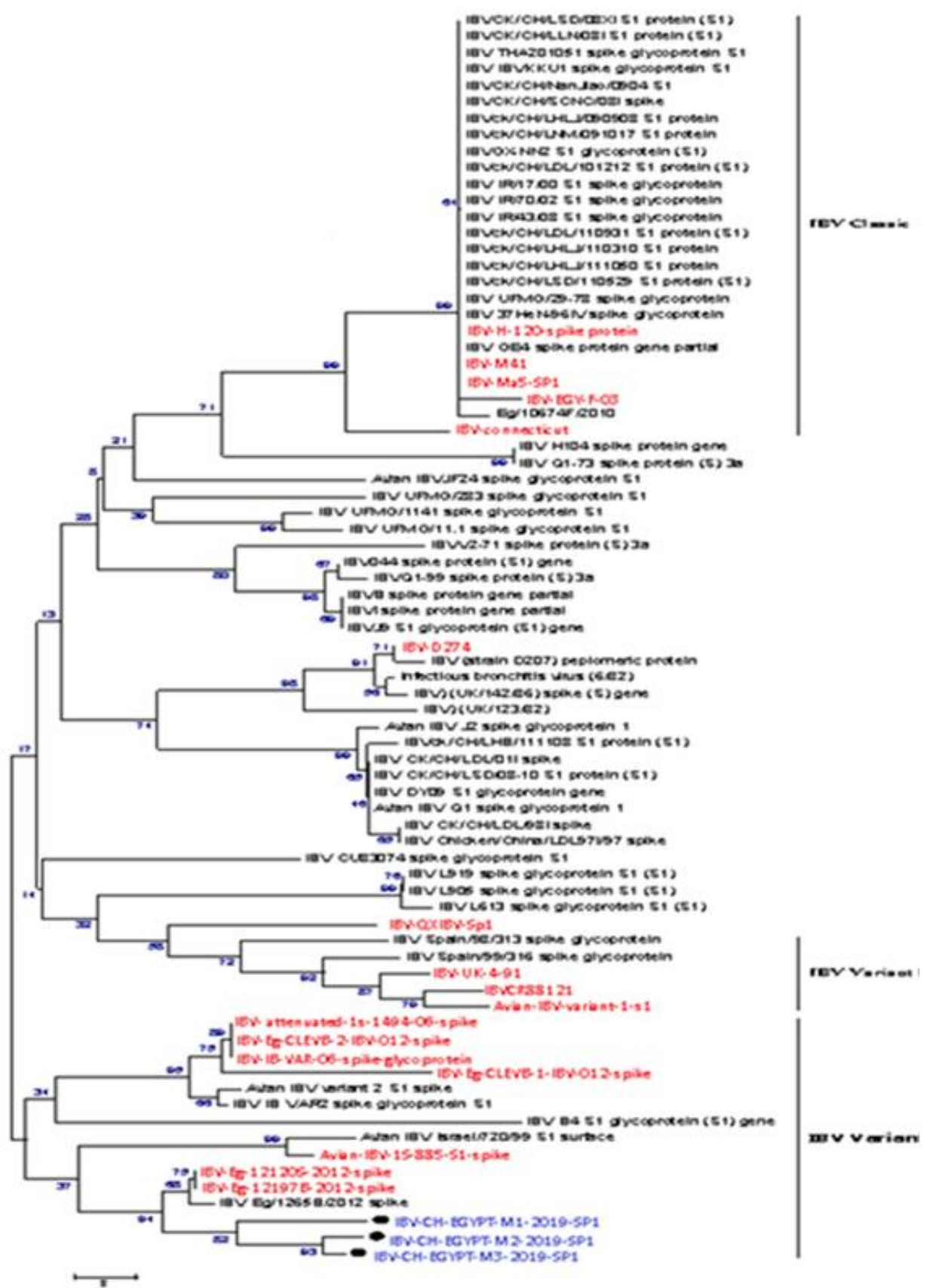

Fig. (2): A Phylogenetic tree of three recent Egyptian IBV strains (with black solid circle and written in blue) with other strains circulating in Egypt and worldwide (written in red). Figure revealed clustering of IBV Egyptian sequences with variant II strains. 


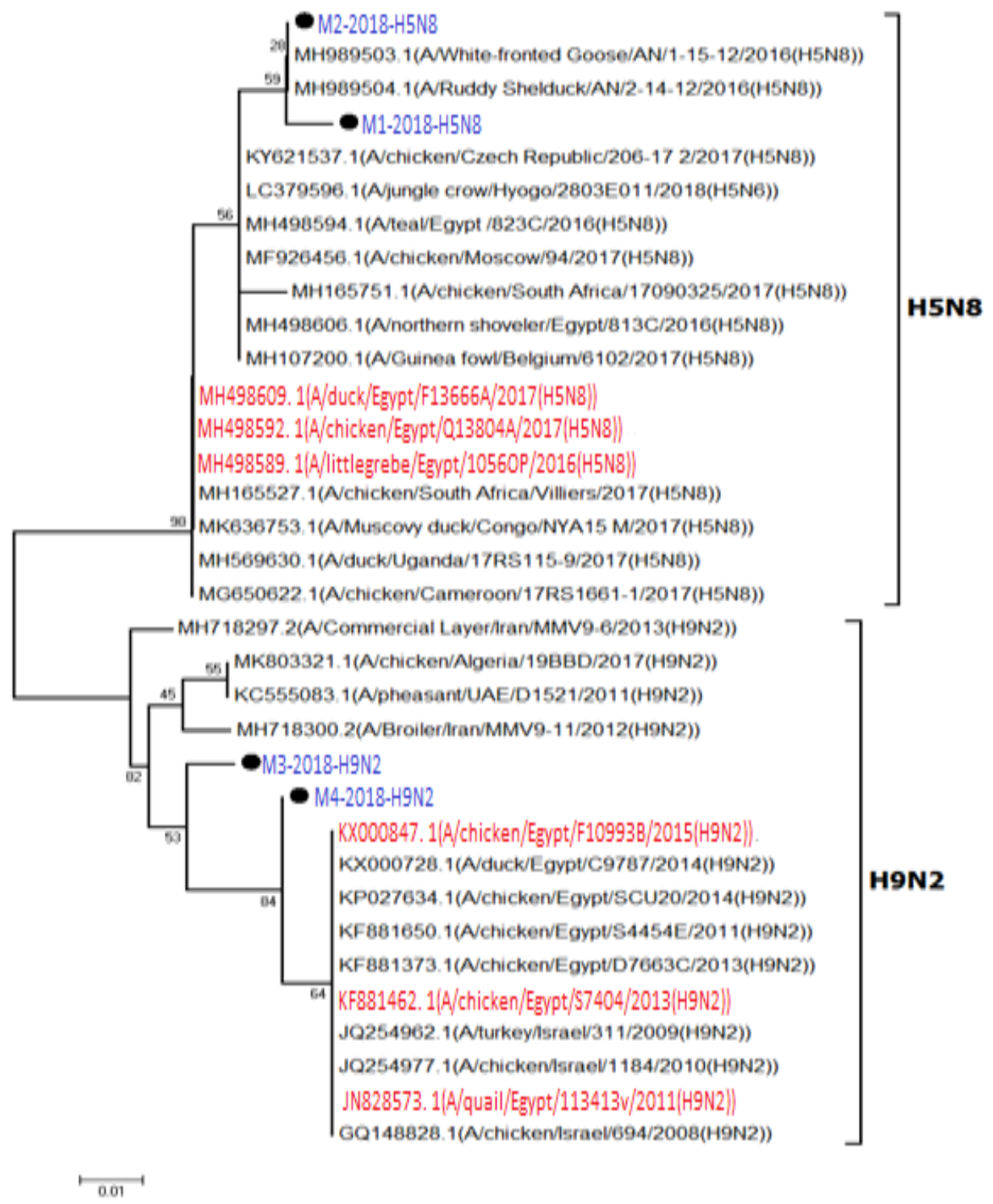

Figure (3): A Phylogenetic tree representing partial nucleotide sequences of $M$ gene nucleotide sequences for four AIV isolates (with a solid black circle and written in blue) compared with other sequences of the reference strains from GenBank (written in red).

\section{Discussion}

Respiratory infection is common and of a major importance in poultry industry worldwide. Respiratory infection in chickens may be as a result of single or mixed infections as many viruses could be involved in the respiratory disease complex. In the present study we detected H5, H9 AIV, velogenic NDV and IBV in several Egyptian farms from 2016 through 
2019. M gene of AIV, S1 gene of IBV and F gene of NDV were sequenced and further molecular characterization were studied to confirm the diagnosis. LPAI H9 was first isolated in Egypt from bobwhite quails and from broiler chickens (20). Co-circulation of $\mathrm{H} 5 \mathrm{~N} 1$ and $\mathrm{H} 9 \mathrm{~N} 2$ avian influenza viruses were detected (21). Cocirculation of both viruses also detected in commercial chicken flocks in Egypt during 2012 - 2013 (22). The main indicator of NDV pathogenicity is the formation of active fusion protein from fusion gene (F-gene), which is characterized by the presence of basic amino acid sequences in fusion cleavage site, therefore, molecular pathotyping and phylogenetic analyses of the $\mathrm{F}$ gene is a major determinant of $\mathrm{NDV}$ virulence instead of conventional methods $(23,24)$.

In the present study Nucleotide and amino acid sequence analysis and phylogeny of the NDV F-gene proved that the obtained isolates are belong to class II, genotype VII. According to evolutionary divergences and alignment of NDV VII with other reference strains in gene bank, it showed that the NDV strains are similar to Chinese viruses (25). Sequencing of the $F$ protein cleavage site corresponding region showed that its amino acid sequence was ${ }^{112}$ RRQKRF $^{117}$, suggesting that our three isolates were vNDV strains as previously reported (26).
IBV causes a contagious respiratory disease in chickens and is one of the important diseases facing poultry industries in the world $(27,8,28)$. several serotypes of IBV have been reported due to the nature of coronaviruses, that frequently show point mutation or recombination, leading to the emergence of new variants. This variant may be due to changes in nucleotide sequence of the $\mathrm{S} 1$ gene, while the IBV genome remains unaltered (29). Based on the obtained $\mathrm{S} 1$ gene sequences the IBV strains detected in the current study clustered phylogenetically in variant II. Variant II IBV strains, is the predominant strain circulates in Egypt during 2012 and 2013 (30). The diversity of the circulating IB viruses in Egypt depend on variations in HVR that can be a complicating factor in the IBV control, moreover, the possibility of recombination between IB viral strains (31). HVRs are associated with a serotype specific epitope which elicits the protective neutralizing antibodies and contains the point mutations that escape the protective antibodies (32).

Avian influenza (AI) is a highly contagious infection of poultry that is caused by avian influenza virus (AIV), once introduced into domestic poultry may emerges genetic shift and/or drift in its two important envelope proteins, hemagglutinin (HA) and neuraminidase (NA) genes, which help virus to escape the neutralizing antibody response from host 
immunity (33, 34). The transmembrane protein of the influenza A virus is an M2 integral membrane protein (ion channel) is the target of antiviral drugs like amantadine and remantadine. Certain mutations in the M2 gene lead to resistant of the virus to antiviral drugs (21). Sequenced $M$ gene of AIV in this study revealed that two isolates clustered in a group related to G1-like lineage of $\mathrm{H} 9$ viruses which are circulating in the Middle East. The cleavage motif of our strain ${ }^{335} \mathrm{RSSR}^{*} \mathrm{GLF}^{341}$ suggesting that our isolates were low pathogenic, the same results were detected by (28). In other article, H9N2 viruses of the HA gene showed that the Egyptian isolates of H9N2 were grouped together within the quail/Hong Kong/G1/97-like lineage, similar to Gaza and Israeli viruses $(20,35)$, while the other two isolates were closely related to $\mathrm{H} 5 \mathrm{~N} 8$ strains isolated in Egypt from 2016 belonging to clade 2.3.4.4.b, that was reported in Russia and further spread to many countries in Europe, Asia and the Middle east.

\section{Conclusions}

From the obtained results, we can conclude that combined pathogens causing respiratory infections in chickens is very common, which leads to the increase in the severity of the disease and the huge economic losses. The frequent detection of AIV, virulent NDV as well as IBV from broiler flocks emphasize the need to review the vaccination strategies based on further epidemiological and molecular studies for improvement in the disease prevention and control.

\section{Conflict of interest}

None of the authors have any conflict of interest to declare.

\section{Reference}

1. Ayim-Akonor M., Baryeh K. and Asante I.A. Molecular Based Survey of Pathogens Associated with Respiratory Disease Outbreaks in Broiler Chickens in Accra. J Nat Sci Res. 3(10): 25-31, 2013.

2. Roussan D.A., Alrifai R.H., Khawaldeh G.Y., Totanji W.S., and Shaheen I. Ornithobacterium rhinotracheale and Mycoplasma synoviae in broiler chickens in Jordan. Rev Sci Tech Off Int Epiz. 30(3): 931-937, 2011.

3. Mehrabanpour M.J., Khoobyar S., Rahimian A., Nazari M.B., and Keshtkar M.R. Phylogenetic characterization of the fusion genes of the Newcastle disease viruses isolated in Fars province poultry farms during 2009-2011. Vet. Res. Forum. 5(3): 187-191, 2014.

4. Radwan M.M., Darwish S.F., El-Sabagh I.M., El-Sanousi A.A. and Shalaby M.A. Isolation and molecular characterization of Newcastle disease virus genotypes II and VIId in Egypt between 2011 and 2012. Virus Genes. 47(2): 311316, 2013. 
5. Alexander D.J. Newcastle disease and other avian Paramyxoviridae infections. In B.W. Calneck (10th ed.) Dis Poultry. p. 541-569, 1997.

6. Kim S.H., Wanasen N., Paldurai A., Xiao S, Collins PL and Samal S.K. Newcastle Disease Virus Fusion Protein Is the Major Contributor to Protective Immunity of Genotype-Matched Vaccine. PLoS. ONE. 8(8): e74022, 2013.

7. Wang J.Y., Liu W.H., Ren J.J., Tang P., Wu N., Wu H.Y., Ching C.D. and Liu H.J. Characterization of emerging Newcastle disease virus isolates in China. Virol. J. 12: 119, 2015.

8. Roh H.J., Hilt D.A., Williams S.M. and Jackwood M.W. Evaluation of Infectious Bronchitis Virus Arkansas-Type Vaccine Failure in Commercial Broilers. Avian Dis. 57(2): 248-259, 2013.

9. Bande F., Arshad S.S., Omar A., Bejo M.H., Abubakar M.S. and Abba Y. Pathogenesis and Diagnostic Approaches of Avian Infectious Bronchitis. Adv Virol. 11: 1-11, 2016.

10. Bozorgi A., Keyvanfar H., Shushtari H., Bahmaninejad M. and Eshratabadi F. Molecular characterization and phylogenetic analysis of hemagglutinin and neuraminidase genes of $\mathrm{H} 9 \mathrm{~N} 2$ avian influenza viruses isolated in Iran in 1999 and 2009. Afr. J. Microbiol Res. 6 (21): 45504556, 2012.

11. Tong S., Zhu X., Li Y., Shi M., Zhang J., Bourgeois M., Yang H.,
Chen X., Recuenco S., Gomez J., Chen L.M., Johnson A., Tao Y., Dreyfus C., Yu W., McBride R., Carney P.J., Gilbert A.T., Chang J., Guo Z., Davis C.T., Paulson J.C., Stevens J., Rupprecht C.E., Holmes E.C., Wilson I.A., Donis R.O. New world bats harbor diverse influenza A viruses. PLOS. Pathogens 9: pp.1003657, 2013.

12. Seifi S., Asasi K. and Mohammdi A. Natural coinfection caused by avian influenza H9 subtypes and infectious bronchitis viruses in broiler chicken farms. Veterinarski Arhiv. 80(2): 269-281, 2010.

13. Zhao M., Liu Q., Sun Q., Zhang W., Zhao G., Gu M., Wang X., Hu S., Liu X. and Liua X. Full Genome Sequence of a Natural Reassortant H9N2 Avian Influenza Virus Isolated from Domestic Ducks in Jiangsu Province, China. Genome Announc. 1(4): 463-13, 2013.

14. Rashid S., Naeem K., Ahmed Z., Saddique N., Abbas M.A. and Malik S.A. Multiplex polymerase chain reaction for the detection and differentiation of avian influenza viruses and other poultry respiratory pathogens. Poultry Sci. 88(12): 2526-2531, 2009.

15. Beard C.W. Serologic Procedures. In: Hitchner S.B., Domermuth C.H., Purchase H.G., Williams J.E. (eds.), Isolation and Identification of Avian Pathogens. American Association of Avian Pathologists: Kennett Square, P.A., USA, pp: 129-135, 1980. 
16. Swayne, D. E., Swnne, D. A. \& Beard, C. W. Isolation and identification of avian pathogens. 4th Ed. American Association of Avian Pathology, Pennsylvania, USA, 1998.

17. OIE. Newcastle disease (chapter 2.1.15) from OIE manual of diagnostic tests and vaccines for terrestrial animals, 2014.

18. Kim, L. M., C. L. Afonso, and D. L. Suarez. Effect of probe-site mismatches on detection of virulent Newcastle disease viruses using a fusiongene real-time RT-PCR test. J. Vet. Diag. Invest. 18:519-528. 2006.

19. Thompson, J.D., Higgins, D.G., Gibson T.J. and CLUSTAL W. Improving the sensitivity of progressive multiple sequence alignment through sequence weighting, position-specific gap penalties and weight matrix choice. Nucleic Acids Res. 22(22):46734680, 1994.

20. El-Zoghby, E. F., A. S. Arafa, M. K. Hassan, M. M. Aly, A. Selim, W. H. Kilany, U. Selim, S. Nasef, M. G. Aggor, E. M. Abdelwhab, and H. M. Hafez. Isolation of H9N2 avian influenza virus from bobwhite quail (Colinus virginianus) in Egypt. Arch. Virol. 157:1167-1172, 2012.

21. Arafa, A., D. Suarez, S.G. Kholosy, M.K. Hassan, S. Nasef, A. Selim, G. Dauphin, M. Kim, J. Yilma, D. Swayne and M.M. Aly. Evolution of highly pathogenic avian influenza H5N1 viruses in
Egypt indicating progressive adaptation. Archives of Virology 157, 1931-1947, 2012.

22. Shakal,M.A.; Youssef, Y.I.; El Seedy, S.A.; Ibrahim, S.M. and $\mathrm{Al}$ Baroudi, B.M.Surveillance onAvian Influenza H5N1 and H9N2 Subtypesin Egypt 2012-2013. Poult Fish Wildl Sci., 2:1, 2013.

23. Mohamed, MHA, Kumar S, Paldurai A and Samal SK. Sequence analysis of fusion protein gene of Newcastle disease virus isolated from outbreaks in Egypt during 2006. Virol. J. 8: 237, 2011.

24. Damena D., Fusaro A., Sombo M., Belaineh R., Heidari A., Kebede A., Kidane M. and Chaka H. Characterization of Newcastle disease virus isolates obtained from outbreak cases in commercial chickens and wild pigeons in Ethiopia. Springerplus. 5: 476-453, 2016.

25. Creelan. L.J., Graham.D.A., McCullough, Samuel J. Detection and differentiation of pathogenicity of avian paramyxovirus serotype 1 from field cases using one-step reverse transcriptase polymerase chain reaction. Avian Pathology, 31 (5), 493-499, 2002.

26. Shabbir M.Z., Zohari S., Yaqub T., Nazir J., Shabbir M.A., Mukhtar N., Shafee M., Sajid M., Anees M., Abbas M., Khan M.T., Ali A.A., Ghafoor A., Ahad A., Channa A.A., Anjum A.A., Hussain N., Ahmad A., Goraya M.U., Iqbal Z., Khan S.A., Aslam H.B., Zehra K., Sohail M.U., Yaqub W., Ahmad N., Berg 
M. and Munir M. Genetic diversity of Newcastle disease virus in Pakistan: a countrywide perspective. Virol J. 10: 170, 2013. 27. Zou N.L., Zhao F.F., Wang Y.P., Liu P., Cao S.J., Wen X.T. and Huang Y. Genetic analysis revealed LX4 genotype strains of avian infectious bronchitis virus became predominant in recent years in Sichuan area, China. Virus Genes. 41(2): 202-209, 2010.

28. Seger W., Langeroudi A.G., Karimi V., Madadgar O., Marandi M.V. and Hashemzadeh M. Genotyping of infectious bronchitis viruses from

29. broiler farms in Iraq during 2014-2015. Arch. Virol. 161(5): 1229-1237, 2016.

30. Kasem S., Abdelkader A., Tahoon A. and Shaban H. Phylogentic analysis of recent infectious bronchitis virus isolates from broiler chicken farms in Kafrelsheikh, Egypt. Benha Vet. Med. J. 29(1): 189-195, 2015.

31. Abdel-Moneim, A. S., M. A. Afifi, and M. F. ElKady.Emergence of a novel genotype of avian infectious bronchitis virus in Egypt. Arch. Virol. 157:2453-2457, 2012.
32. Liu S., Xu Q., Han Z., Liu X., $\mathrm{Li}$ H., Guo H. Origin and characteristics of the recombinant novel avian infectious bronchitis coronavirus isolate ck/CH/LJL/111054. Infect Genet Evol. 23:189-195,2014.

33. Koch G., Hartog L., Kant A., van Roozelaar D.J. Antigenic domains on the peplomer protein of avian infectious bronchitis virus: correlation with biological functions. J. Gen. Virol. 71(Pt 9):1929-1935, 1990.

34. Lee C.H., Byun S.H., Lee Y.J. and Mo I.P. Genetic evolution of the H9N2 avian influenza virus in Korean poultry farms. Virus Genes. 45: 38-47, 2012.

35. Elzahed M.E., Arafa A., Elsanousi A.A. and Shalaby M.A. Isolation and characterization of avian influenza from different species of ducks in delta region. Egypt J. Virol. 12: 1-9, 2015.

36. Shen H.Q., Yan Z.Q., Zeng F.G., Liao C.T., Zhou Q.F., Qin J.P., Xie Q.M., Bi Y.Z. and Chen F. Isolation and phylogenetic analysis of hemagglutinin gene of H9N2 influenza viruses from chickens in South China from 2012 to 2013. J. Vet. Sci. 16(3): 317-324, 2015. 


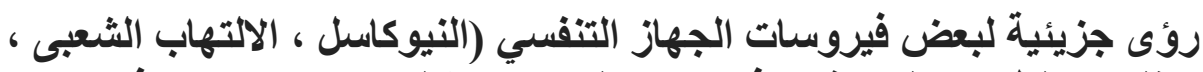

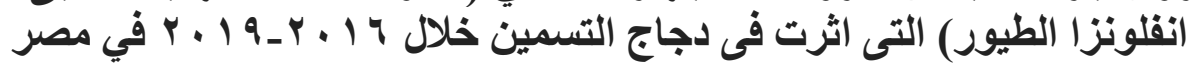

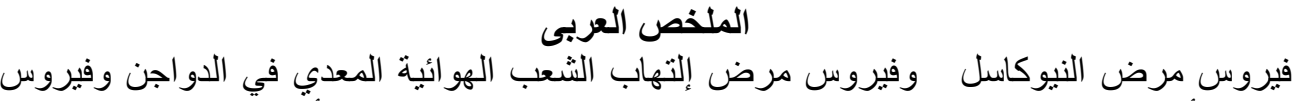

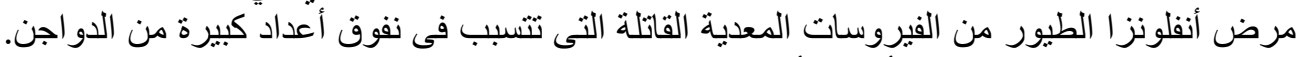

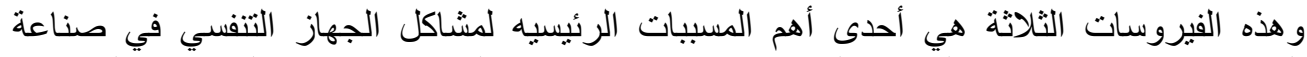

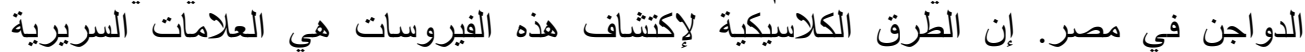

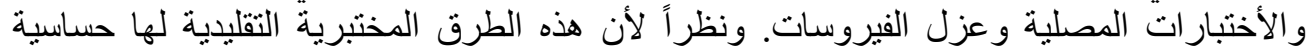

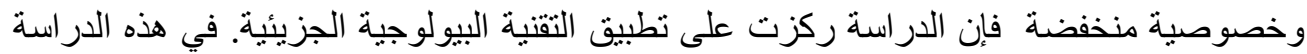

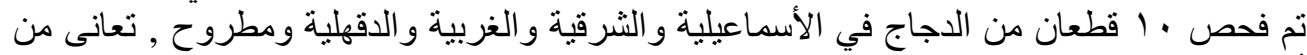

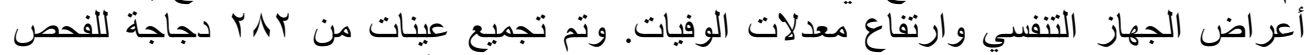

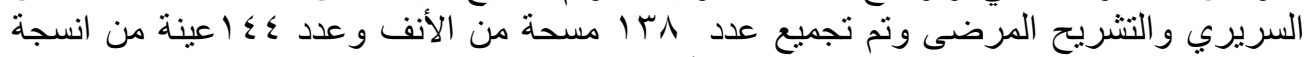

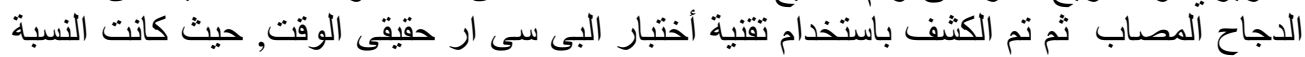
الايجابية لكل فيروس كالتالى فيروس النيوكاسل

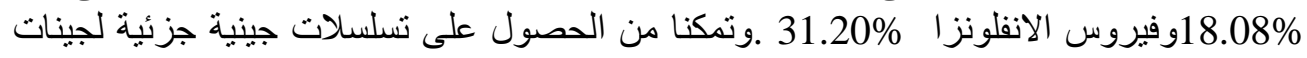

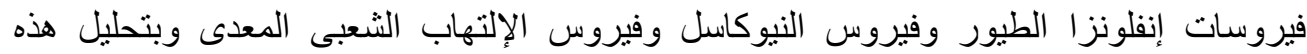

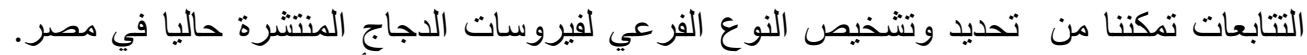

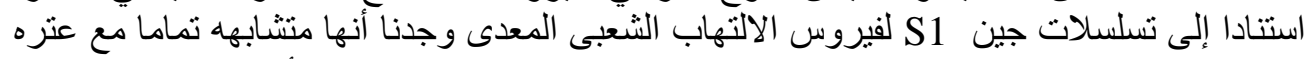

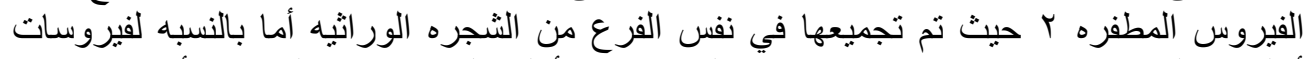

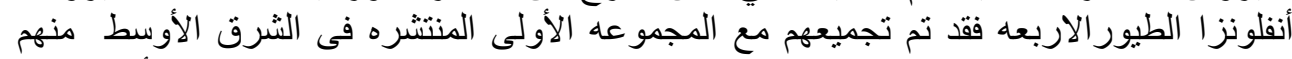

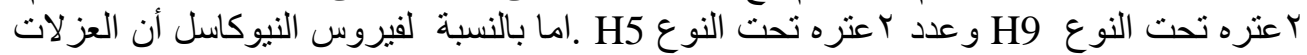

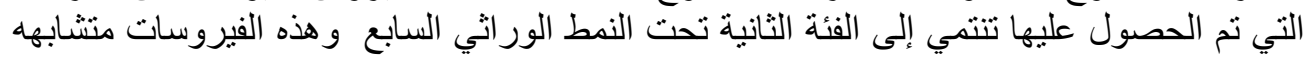

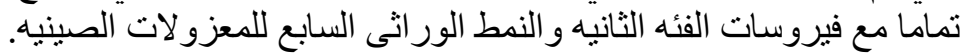

